\title{
Lucian Pintilie and Censorship in a Post-Stalinist Authoritarian Context
}

\author{
Emanuel-Alexandru Vasiliu \\ Apollonia TV, Iași, Romania \\ Email: emanuel.vasiliu@arteiasi.ro
}

How to cite this paper: Vasiliu, E.-A. (2019). Lucian Pintilie and Censorship in a Post-Stalinist Authoritarian Context. Psychology, 10, 1159-1175.

https://doi.org/10.4236/psych.2019.108075

Received: May 21, 2019

Accepted: June 27, 2019

Published: June 30, 2019

Copyright $\odot 2019$ by author(s) and Scientific Research Publishing Inc. This work is licensed under the Creative Commons Attribution International License (CC BY 4.0).

http://creativecommons.org/licenses/by/4.0/

\begin{abstract}
The objective of my work is to shed light on the way in which the post-1953 ideology of the Romanian Communist Party influenced Romanian theatre and film director Lucian Pintilie's career, resulting in a ban to work in Romania. Reacting to the imposition of the cultural revolution and against the laws of coagulating the socialist realist work of art, Lucian Pintilie managed to mark the Romanian theatrical and cinema landscape through the artistic quality of the productions and the directed films, replicated by the renown of the imposed interdiction.
\end{abstract}

\section{Keywords}

Lucian Pintilie, Censorship, Ideology, Theatre

\section{General Presentation}

Ceauşescu's Romania was a closed society, characterised by repression in all fields of human existence: limitations of ownerships rights, hard labour conditions and small wages, lacking freedom of movement, bureaucratic obstacles against emigration, violations of the rights of national minorities, contempt for religious faiths and the persecution of religious practices, drastic economic austerity, constant censorship in the field of culture, the repression of all dissident views and an omnipresent cult around the president and his family, which contributed to the demoralisation of the population. In the field of intellectual life, the aim of the communist party was that of annihilating any form of authentic creativity: literature, history, art and philosophy had to ideologically subordinate to the political sphere. The entire cultural tradition was reinterpreted to conform to the new dogma: the main personalities in Romanian literature were eliminated form official publications, censorship was applied drastically to eliminate 
anything resembling "nationalism", "cosmopolitanism", "objectivism" or other forms of "bourgeois decadence".

On the occasion of the ascent to power of the communist party in Romania, very active propaganda was initiated in the fields of arts and sciences, meant to show the population the benefits, achievements and good will of the regime and of the Romanian-Soviet friendship. The works of Lenin and Stalin were distributed in companies, factories and plants, with the propaganda work being completed by mammoth meetings, where politicians such as Gheorghiu-Dej, Ana Pauker or Vasile Luca would hold speeches. In the press, articles such as "The miner Copetin Geza reached more than two target figures in a single shift" or "Towards the strengthening of agricultural association in the commune Dumbrava" are examples of propaganda which evolved tirelessly and continuously. Theatre plays and compositions of classical Russian authors such as Tchaikovsky or Gorky were played at the opera, in theatres and in the Romanian Atheneum. Propaganda was especially active in cinema. With the help of SovRom Film and Cinexfilm, Soviet films such as The Sailors on the Baltic were being imported and screened, showing how a true revolutionary who sings the Internationale behaves when his ships sinks. The waycommunist justice worked to ensure peace and order in the labourers' land would also be shown in cinema. In the arts, the image of Stalin, Lenin and the labourers would be extolled, sometimes allowing for elements from the past of the country. Another propaganda element intensely used by the communist regime was historiography, a field manipulated and manoeuvred by altering historical truth to coincide with the plans and wishes of the party. During Ceauşescu's visit in Asian countries, he was impressed by the praises brought by the local people to their leaders, so that the era of Ceauşescu's personality cult would begin, leading to an explosion of propaganda. Personalities who adjusted to Stalin's guidelines were writers Mihail Sadoveanu, Alexandru Toma, Eusebiu Camilar, Victor Tulbure, Eugen Barbu and Mihai Beniuc, film director Virgil Calotescu, painters Camil Ressu, Corneliu Baba, Constantin Piliuță and Theodor Harşia.Among those who did not follow those criteria were Monica Lovinescu, Mircea Eliade, Radu Gyr, Nichifor Crainic, Emil Cioran and Mircea Vulcănescu.

Lucian Pintilie was born in 1933 in Tarutino, Bessarabia. After graduating the Institute of Theatre and Cinema in Bucharest, he staged a series of performances at the Bulandra Theatre in Bucharest, among which: Children of the Sun (1961), The Fools under the Moonlight (1962), Caesar and Cleopatra (1963), The Fire Raisers (1964), My Heart's in the Highlands (1964), D'ale carnavalului (1966), The Cherry Orchard (1967), The Government Inspector (1972, a performance banned by censorship after the $3^{\text {rd }}$ representation), as well as directing two feature-length films: Sunday at Six and Reenactment. The ban to work in Romania determines him to expatriate in 1973. He continued abroad the series of theatre performances staged on some of the world's most important stages: Théâtre National de Chaillot in Paris: Turandot (1974); Théâtre de la Ville in Paris: The 
Seagull (1975), The Fire Raisers (1976), Jack, or The Submission and The Future is in Eggs (1977), The Last Ones (1978), Three Sisters (1979), The Wild Duck (1981), The Lower Depths (1983), Arden of Faversham (1984), Tonight We Improvise (1987), The Dance of Death (1990); Guthrie Theater in Minneapolis: The Seagull (1983), Tartuffe (1984), The Wild Duck (1988); Arena Stage in Washington: Tartuffe (1985), The Wild Duck (1986), The Cherry Orchard (1988). In parallel, he also staged opera performances: The Festival of Avignon: Orestia (1979); the Festival in Aix-en-Provence: The Magic Flute (1980, a performance restaged at the Opera in Lyon, the Opera in Nice, Teatro Reggio in Torino); Welsh National Opera in Cardiff: Rigoletto (1985); Carmen (1986, a performance restaged at the Opera in Vancouver). In 1973 he directed the film Ward 6 at the Yugoslav television, after Chekhov's homonymous short story. In 1979 he filmed Carnival Scenesin Romania after his own script departing from the play $D$ ale carnavalului, a film forbidden for ten years. After 1990 he repatriates and makes a series of films in Romania: The Oak (1992), An Unforgettable Summer (1994), Too Late (1996), Next Stop Paradise (1998), The Afternoon of a Torturer (2000), Niki and Flo (2003), Tertium non datur (2006). In 1990 he was named Head of the Cinema Studio of the Ministry of Culture, a position he used to support films made by young Romanian directors.

Lucian Pintilie graduated the Institute for Drama and Film in Bucharest, Romania, in 1956 under the directing teacher George Dem. Loghin. According to his testimonies set in narrative form in an interview given to the magazine Positif, republished in translation in the collection of personal notes and performance reviews Bricabrac, censorship affected him for the first time "in the $3^{\text {rd }}$ year of the theatre course", when he was "evicted from the Institute (and accepted back subsequently)" (Pintilie, 2003). His perspective on the interaction with censorship has the form of a series with fast-developing episodes: "Then [...] I was evicted from the first theatre where I had been employed, I was sacked from television. 'Lucian Pintilie will never work in the ideological-artistic field again' predicted then a 'more rigid' bigwig with predestined name-Topor (axe)." (Pintilie, 2003) The case from 1963, when the staging of the play The Fools under the Moonlight at Bulandra Theatre was halted, brings with it the first reference to the political context that the director describes as a point of entry "in a hypocritical liberal period" (Pintilie, 2003).

\subsection{Socialist Realism versus Bourgeois Mentalities}

That period developed especially after 1965, when the falling out of grace of socialist realism as a creative method did not mean the reconsideration of the artists who had suffered in the period of its rule, less so of those who had stayed abroad, such as Nina Diaconescu, Raluca Sterian, Ana Maria Narti, George Dem. Loghin, Ana Novak. According to a statistical sheet issued by the Section for Propaganda and Agitation, a note regarding the opening of party education, signed by Paul Niculescu Mizil and Ion Iliescu, on 1 November 1966 over 1665 
000 students were enrolled in party education, with artists being subjected to the category "other intellectuals", whose number was difficult to appraise. The theatre practitioners who had suffered under socialist realism were eliminated from the historical syntheses of Romanian theatre; the plays in which they had interpreted disappeared from repertory lists. In the best cases, the plays were mentioned but the contribution of the "fugitives" (text/directing/stage design/intepretation) was deleted together with their names. However, the artistic, publishing and memoir activity of emigrated artists was followed, even if by a restricted group of Romanians - the leaders, instructors and other activists of the ideological sections of the RCP CC. The theatres (especially those in Bucharest: the National, Bulandra, the Comedy, Nottara, etc.) sought to distinguish themselves through a repertory assembled out of works signed by Western playwrights; it was also a way of communicating more easily with the outside world in an era in which, as opposed to the 1950s, it was much easier to leave on a tour abroad. Because of the fact that many actors also took part in film shootings, their frequency in attending ideological courses was lower as compared to writers. In cinema, Mihnea Gheorghiu had become of favourite of N. Ceuşescu in the field. The ideological potential of both arts through propaganda is illustrated in a declaration given by another Ceauşescu favourite, Aurel Baranga, regarding the situation of television. According to him, "The discussion of the activity of television, like the discussion of editorial activities, has to bear the sign of the indications given by comrade Ceauşescu on multiple occasions and at the then recent plenary of the Front of Socialist Unity, when he appealed to the activation of all levers of our propaganda apparatus. [...] Our television station must give priority to that art, which best represents socialism in matters of art, theatre, poetry." (Central Historical National Archives, 1970) Among the ideological formulations featured in the "Theses of July 1971", the revision of film imports, and plays and film scripts to be ordered to creators were ranked highly in the series of measures.

The liberal charactermentioned by Lucian Pintilie was conveyed by the situation in a stage of so-called ideological "thawing", which came about after I. V. Stalin's death in 1953, an event which also marked "the end of socialist realism proper” (Şendrea, 2014). In February 1956, Nikita Khrushchev had presented a secret report on the occasion of the $20^{\text {th }}$ congress of CPSU. In April the magazine Teatru (Theatre) is published, as an "organ of the Ministry of Culture and the Writers' Union from PRR", "less altered by ideological texts and bearing prestigious signatures like those belonging to Tudor Vianu, Camil Petrescu, Tudor Arghezi, Lucia Sturdza-Bulandra [...], Liviu Ciulei, Pentru Comarnescu but also" (Vasile, 2011) to the younger Ştefan Augustin Doinaş In the summer of the same year, the National Theatre of Bucharest was on tour in the capital of France, the first manifestation of such range in the West after political power had been taken over by the communist rulers. The Romanian state resumed participation in the Art Biennale of Venice in 1956. Representing Romania at the 
Biennale, Jules Perahim would sign the stage design of the performance The Fire Raisers, staged by Lucian Pintilie at the Bulandra Theatre. Simplifying, the hypocrisy of this liberal period, in the director's view, can be explained through the discrepancy between the diplomatic actions undertaken by the state and the censorial practice manifested inside the country. In 1958, Romanian dramatist Ana Novac's career received a heavy blow: the play Ce fel de om eşti tu (What kind of man are you) was attacked in Scânteia and then in other newspapers, being denounced as a "damagingplay" which would be based on a "false vision on the whole work of constructing socialism" (Selejan, 1999). She was exposed in a public meeting; this would be the end of her writer's career in communist Romania since, as opposed to other intellectuals and artists, Ana Novac did not admit any wrongdoing. After several failed attempts, she managed to emigrate in 1965. If the first edition of her memoires (from 1966) - published in Hungary in Hungarian-did not cause a reaction in Bucharest, the ideological powers-thatbe got wise to the fact a year later, when the publishing house Rowohlt in Hamburg prints Ana Novac's autobiographical work (he real name was Zimra Harsányi; among other things, she was a survivor of the Holocaust, having been imprisoned at Auschwitz). Predictably, after 1965, Ana Novac's ten theatre plays were never mentioned anymore.

In effect, censorship equalled the political and ideological control meant to restrict the forms of expression to the exactingness of the socialist realism, declared as the only approved aesthetics as a consequence of the Romanian state being included in the Soviet sphere of influence beginning with 1944. The latter had gone through a cultural revolution from 1928 to 1931, necessary in order to consolidate the regime through new social and cultural norms and favoured this "aesthetics which used $19^{\text {th }}$ century realistic techniques to describe idealised, heroic individuals in an optimistic light. Socialist realism was used to paint a positive and largely fake image of the Soviet Union for the people, thus harnessing its efforts to the construction of the new state. Imposing the aesthetics necessitated ostracising the revolutionary diversity of artistic views of the USSR, since the experiment, questioning the existing modes of seeing were now antithetical with the state project, being condemned as 'formalism' and 'bourgeois decadence"' (Counsell, 1996). "For the new man who was being born a new reality was necessary, one which should be recognisable and understood by the masses (figurative representation in the fine arts, classical narrative structures in cinema and theatre, cancelling all avant-garde experiments.)" (Şendrea, 2014). In order to qualify as socialist realistic, works of art needed to observe the four laws established by I. V. Stalin in 1934: realism-the work of art has to agree with and to promote the Soviet and Marxist-Leninist ideology; proletarian-the work of art must be imbued with class conscience, the heroes (and antiheroes) must be outlined along the principles of belonging to a certain social class and the outcome must confirm the implacable progress of history in the sense of the Marxist vision: illuminating the class conscience of the working hero (occasionally peasant 
or enlightened intellectual) and the victory of the proletariat over the oppressive classes; partisan - "the leading role of the Party must be obvious and emphasised, often through the physical presence of a Party official [...] who guides the hero, and through references to the specific iconography"; and typical- "the content of the work of art must represent the interests and the points of view of the people and do this in a way which is understandable for them." (Andrei Șendrea, 2014).

\subsection{The Apparatus of Censorship}

Stalin's four laws were supported by a system with roots in the Bolshevik censorship but also with local origins in the military censorship during World War II. The Romanian system was headed by the Secretary General of the RCP, assisted by the Political Bureau (the Propaganda section) of the CC of the RCP. The first step in the direction of a statute of control over information in Romania is considered to be the changing of the Press and Print Directorate within the former Ministry of Arts and Information in the General Directorate of Press and Print, which would function by the Council of Ministers of the Romanian People's Republic. The change was published in No. 23 (May 1949) of the Official Bulletin of the Romanian People's Republic as article 2 from Decree no. 214. (Ficeac, 1999) The specific responsibilities of this $3^{\text {rd }}$ level of censorship (after the Secretary General of the RCP and the Political Bureau-the propaganda section) were described in a "measure plan for the improvement of the situation in the field of literature" of 25 October 1955: "The General Directorate of Press and Print will observe the legal deadline of reading the manuscripts and the columns with a view to awarding the good for print or the good for diffusion. The General Directorate of Press and Print will strictly observe its attributions. Any observations on the literary works, which surpass the attributions of GDPP, will be signalled to the boards of the respective magazines and publishing houses, which take responsibility for publishing those works." (Vasile, 2011)

As far as the theatre performance were concerned, the unit tasked with censorship bore several names, "The Council of Socialist Culture and Education" was preceded by "The State Committee for Culture and Art" and by "The (General) Directorate of Theatres from the Ministry of Culture". In the early 1950s, this unit imposed repertoires to theatres. Because of the practical impossibility of strictly observing an imposed repertoire, the system is modified in several stages, first by establishing a list of banned titles and texts recommended for staging, out of which theatres could choose. Subsequently, the lists would give way to criteria "of assembling the repertoire, which would be put together by the board of the theatre but approved by the General Directorate of the Theatre, after successive checks." (Malița, 2006). These were based on the papers in support of the plays, drawn up within the Literary Secretariate of the theatre. The Theatre Directorate, "through its own instructors, was analysing the repertoire proposals and holding talks with a view to shaping the repertoire according to party indi- 
cations.” (Malița, 2006). “Among the main deficiencies of the season 1965-1966, the following were listed: the contemporary profile of the repertory was not stressed; several performance categories were underrepresented (Romanian plays, in general); there were too few premieres which could reach the status of works of national dramaturgy, which truly represented values of Romanian classical dramaturgy, too few performances of a historical character and works glorifying the struggle of the working class and communists; on the other hand, foreign contemporary dramaturgy was overrepresented." (Central Historical National Archives, 1966). "The 1960s, up to the theses of July 1971, also witnessed the privilege of dampening the ideological criteria in favour of the professional ones." (Malița, 2006). Although the consequences of the censorship in the communist times reach the contemporary period (proof being the non-inclusion of the film Carnival Scenes in the manifestations organised in 2002 by the Romanian Embassy in Paris through the Romanian Cultural Centre on the occasion of celebrating 150 years from Caragiale's birth), stricto sensu, Lucian Pintilie was affected by censorship from 1962 to 1981, years marking the banning of the staging of the dramatic text The Fools under the Moonlight and of the film Carnival Scenes. In this period, the Romanian state passed through several stages of evolution, with the year 1971 marking harsher ideological conditions.

\section{From the History of Censored Works}

\subsection{The Fools under the Moonlight (1962-1963)}

Stepping back in time, the performance The Fools under the Moonlight (Bulandra Theatre, 1962) was modified several times on the recommendations of a viewing committee, with a consequence in weakening it and having it banned despite the implemented changes. Although it featured lines like "The cultural revolution seemed to her the shortest way to my wages. By coming to love my wages, she had come to love the cultural revolution." (Mazilu, 1971), the dramatic text The Fools under the Moonlight had been approved for staging. The Directorate for Propaganda and Culture, the ideological body of the RWP Central Committee, reacted to Nicolae Ceauşescu's halting the representations of the staging at the Bulandra Theatre by sending a viewing committee to make changes to the text. We can suppose that lines such as "A woman of today, if she wants to turn men's heads, must take the occasioned changes into account. [...] It's harder than during bourgeois times... It's not enough to have a beautiful body, you also need a soul to match. [...] And a little bit of respect for the achievements of the regime... [...] You must be preoccupied with your man's work, you must share his aspirations. [...] If he believes in socialism, you must also;" (Mazilu, 1971) would have been the object of suppression. Although, according to some testimonies, "usually censorship was applied orally, through indications of changes to the text, which was submitted to several sessions of 'verification' reading" (Popescu, 2004), the staging had censored scenes; thus, "The first theatre scene that the party banned was the scene of the women abandoned 
by Gogu, who committed suicide by throwing themselves, head down and legs up, in the abysmal pit of the piano, accompanied by the interpretation of Pyotr Ilyich Tchaikovsky's Concerto No. 1 for piano and orchestra." (Pintilie, 2003)

"For the first time in my life, I tried to appease the censors by attenuating the production. They returned, saw it and banned it again. So I gave in again and attenuated the production even more. I remember the day when they came for the third time, watched the play and left without saying a word. Then I realised you must never negotiate with that type of attitude. You must never resort to the taste of the majority. There is nothing to win. You only destroy the dignity of the work." (Richards, 1986). The dramatic text written by Teodor Mazilu in Bucharest, from June 1961 to May 1972 was published for the first time in a volume ten years later (Teatru (Theatre), Bucharest, Cartea românească, 1971). Thus, there are signs that the trauma of having the staging The Fools under the Moonlight banned, a performance described by the director as a "genious, winged [...] child" (Pintilie, 2003) led to a subsequent uncompromising attitude towards censorship.

\subsection{Carnival Scenes (Film House 5, 1979, 35 mm, Colour)}

Ten years after the dismissal of the Bulandra Theatre management in the party meeting which followed the third representation of the performance The Government Inspector, Lucian Pintilie addressed a text to the Secretary of the Propaganda section of the RCP CC (Tatos, 2010). Ilie Rădulescu, who had presided over that meeting, presenting the chronology of censoring the film Carnival Scenes. Thus, on 19 June 1981, "a 100\% viewing of the film material is organised for the managing board of Film house 1. At the end of the screening from 19 June, Marin Theodorescu (prospective manager) ascertains that the democratic protocol was not fulfilled: 'We are half minus one. ${ }^{1}[\ldots]$ Comrade Potângă has to see it.”' (Pintilie, 2003) (Ilie Rădulescu's former head of cabinet had excused himself "a second time from the screening") (Pintilie, 2003). On 23 June a screening takes place with comrade Potângă. "On the following days, other screenings took place, accompanied by a few director colleagues: 'We want to speak directly to colleague Pintilie"' (Pintilie, 2003). The material of the film was confiscated and stored in what is now The House of the Free Press.

\subsection{Jerusalem}

Lucian Pintilie's confrontation with censorship was not limited to the period of the socialist regime in Romania, as the director was confronted with what he called the French "popular censorship" on the occasion of a film project withdrawn in the year 2000 "for lack of money". Having as a theme pedophilia, the script entitled Jerusalem was reproached the absence of a condemning attitude: "You do not seem to express neither a moral, nor a social judgement and not even a reprobatory one concerning this relationship between Frédéric and Jéru-

${ }^{1}$ Marin Theodorescu had been part of the viewing committee who had participated prior to 19 June 1981 in the screenings of the filmed material. 
salem. Could it be because you do not want to condemn them?" (Pintilie, 2003). The answer of the author of the script expresses the difference between a moralising attitude and the description specific to arts: "No, I do not condemn Frederic and Jerusalem. [...] Condemnation does not regard me, it comes from the mechanism and the internal articulations of the story, from its eschatological perspective." (Pintilie, 2003). Also, "Of course that the preoccupation of religion is to chastise, not so of literature, which rather brings an unsettling testimony of suffering and curse, without the obsession, the fixed idea of condemnation." (Pintilie, 2003). As opposed to the censoring authorities of the Romanian communist regime ("bourgeois mentalities" in The Fools under the Moonlight, ridiculing the police and the popular masses in Reenactment, criticising Leonid Brezhnev in The Government Inspector), the case of censoring the film project Jerusalem belongs to an area of taboos, which existed at that moment in France.

\subsection{A Representative Case: Reenactment (1969)}

Perhaps the most telling instanciation of Lucian Pintilie's rebellion against the ideological status-quo comes from the criticism applied to the latter twoof Stalin's laws, visible in the second film directed by Lucian Pintilie. I will take as an example a dialogue between the representative of the state, the prosecutor played by George Constantin, and the unruly young men. The prosecutor: "now they have graduated from high school, for better or for worse, they have sat their A-Levels, they can go to university [...]" (on the soundtrack, the noise of a thunder anticipates the coming rain and is followed by the sonic signal of a locomotive) (Transilvania Film, Filmex, 2013). The prosecutor is interrupted by the amateur movie-maker, who draws his attention to the fact that he "took a stand" from a lamp. The prosecutor takes it out of his pocket, returning it. Then he continues his phrase: "in the future, they should not relent. If now, after graduating from high school [...] they broke the head of a measly waiter..." In the second plane, the warrant officer lights up two lamps, rendering a mock official character to the prosecutor's final wish: "I wish to them that after graduation [...] they hospitalise the entire faculty, headed by the dean, if possible." (Transilvania Film, Filmex, 2013) The character of the warrant officer, played by Ernest Maftei, illustrates the criticism brought against the typical feature of the socialist realistic work of art. Out of the warrant officer's costume, the cap represents the regime-specific iconography. Taking it upon himself to explain to the youths what the "educational" film consists of, the warrant officer derives symbolic authority from the state arms, while the scene of re-enacting the young men's party culminates in a shot in which, under the marked surveillance of the warrant officer cap, the two take glasses from the table and let them fall onto the terrace floor. The filmic criticism of the authority representatives (warrant officer, prosecutor) caused the activation of the ruling forces; on 10 February 1970, the secretariat of the Central Party Committee holds a debate on the topic, in which Ion Iliescu demands "there to be rigorous control from beginning to end, from the 
very conception of the film, from the director's political concept and that only films are made which present all guarantees from the political and ideological point of view.". Brought up out of explanatory reasons, the relationship between artists and cultural clerks is described in the terms of insuccess: "I have talked to Pintilie, the director of the film Reenactment. They are all devoid of receptiveness to any critical observation, they are conceited people, they look down on criticism and disconsider the capacity of political activists to opine on what activity in cinema means." The RCP Secretary General's decision was in favour of continuing the screenings of Reenactment (these took place during three weeks), drawing attention, however, to a closer adherence to the political principles: "in the mean time, we should take measures to only make films which correspond. We should also tackle serious issues, critical of the negative phenomena in our society, from the activity of our bodies. We should not be afraid of tackling these phenomena but we should tackle them in reality, not with silliness, not by stupefying our youth, which does not correspond to reality." (Boia, 2016)

As opposed to the warrant officer or the prosecutor, the teacher was coming close to the definition of the "bourgeois" at least from the perspective of his humanist discourse, specific to Western society. Developed beginning with the $16^{\text {th }}$ and $17^{\text {th }}$ centuries, the tradition of humanism imagined an autonomous citizen, supported by a legal discourse in which the individual creates social-economic relationships, rather than adhering to ones conveyed from top to bottom. Rationalism and the empirical sciences predicated a subject, whose vision and understanding of phenomena was objective and trustworthy, who could reach truth independently of any external agency (Counsell, 1996). In his work dedicated to censorship as it is revealed by laws and documents of news journalism, Bogdan Ficeac approximates the effect of collocations such as "bourgeois mentalities", which, summarises the author, "had come to represent all the worst, most retrograde, most noxious there was for the development of the human being. The respective notion had been completely voided of connotations like the possibility of the individual to freely express himself, often critically, as regards political ideas or politicians, to look for alternatives, etc. By reaction, the word mentality itself, without any attribute, had come to have negative resonance. In the same way, for example, the ban on discussing concepts induced negative resonance to the word 'to interpret'. The expression 'I do not want it to be interpreted' was not followed by the explanation 'as good' or 'as bad', because the action of interpreting in itself represented a negative phenomenon." (Ficeac, 1999)

Thus, the ways in which Lucian Pintilie was affected by censorship can be partly explained by the contrast between socialist realism and the values of "bourgeois" thinking.

\section{The File "Bulandra"}

\subsection{The Central Historical National Archives}

The echo of the director's long-standing collaboration with the Bulandra Theatre 
can be researched in the Central Historical National Archives. From the Section of Propaganda and Agitation comes file 18/1971 (Central Historical National Archives, 1971), which features anonymous letters addressed to Elena Ceauşescu regarding "inadequacies" signalled in the activity of the "Bulandra" Theatre. The acts frame the banning from 30 September 1972 of the performance The Government Inspector, beginning with an informative note, followed by a protest memo against the manager of the institution, Liviu Ciulei, dated December 1971. A copy of the communique from the daily Scînteia (The Spark) is followed by a new letter, which summarises the anti-communist attitude of the so-called, by Ion Brad (vicepresident of the Council of Socialist Culture and Education), "group of blue blood" ("[Nicky] Wolcz, [Emmerich] Schäffer, Vichi Deianu, [Dan] Jitianu, Irina Petrescu [...], Clody, Pintilie, Rebengiuc, Ica Matache, Cotescu, Caramitru, Patrichi, Tapalagă") praising, at the same time, "the daily Scînteia" for having "proven once again the consistency of the party in supporting art for the people." (Central Historical National Archives, 1971). Marian Popescu noticed that using the strategy of a published denouncement ("A great number of spectators addressed themselves to the Council of Socialist Culture and Education by expressing their protest and dissatisfaction as to the way in which N. Gogol's play The Government Inspector was staged at the 'Lucia Sturdza Bulandra' Theatre" (Central Historical National Archives, 1971)) had a precedent in a conflict with the Soviet censorship from 1965, when the performance Dead and Alive directed by Iuri Liubimov, using poetry by Boris Pasternak, had been criticised through "a reader's letter" published in the daily "The red star" (Popescu, 2004). It must be signalled that the period when the protest memos were drawn up (December 1971-October 1972) comes after the "Documents"-the theses of 6 July 1971. These represented invokable acts, which conferred legitimacy beyond personal antipathy.

Here are the ways in which the anonymous groups of actors related to the "Documents": "On 7 December of this year, in the trade-union theatre meeting [...], the management is opposing its own undertakings, which it assumed on the occasion of the documents in July [...]. The little hope that had appeared [for actors, workers] on the occasion of the Documents, when the manager had made pledges on tens of pages with tears in his eyes, is swept away." (Central Historical National Archives, 1971)

The importance of the theses for the group of "unwanted" actors transcends the melodramatic tone, transparing from a separate chapter entitled "The resistance to the July documents". Here are quoted as examples performances directed by Lucian Pintilie: "What does our people, our national art have in common with these practices, these 'directorial' inventions [...] Leaving aside The Fools under the Moonlight, The Hood over the Eyes, the rehearsals with The Government Inspector and many, many others." (Central Historical National Archives, 1971). "The pledges made by the management on the occasion of processing the Documents, when he said [Liviu Ciulei, o.n.] that he would fight 
so that everyone is ok" (Central Historical National Archives, 1971) are contradicted, in the anonymous authors' view, by the "open class struggle, with unequal forces" (Central Historical National Archives, 1971) in the theatre. Invoked in the protest memo out of material (istic) reasons (favouring some actors over others) "the class struggle" was part of the vocabulary of the cultural revolution, within which the Romanian socialist state publicly claimed to be from the early 1960 (as proof, the volume Moments of the cultural revolution in Romania, by Ştefan Bălan, Ilie Murgulescu, George Ivaşcu et al., Ştiințifică publishing house, Bucharest, 1964). Borrowed from the Marxist-Leninist ideology, the cultural revolution stipulated 'the democratisation' of culture, the equalling of cultural conditions, the fast raise in the educational level, as well as the creation of a new intelligentsia related to the people, the working class." (Vasile, 2011). Although there is no direct correspondence between the cultural revolution in the USSR (1928-1931) and the Romanian process (with the possible exception of removing the group Ana Pauker-Vasile Luca, which also meant "the estrangement of several 'bourgeois' specialists" (Vasile, 2011)), the use of the collocation "class struggle" relied historically on the dispute between proletarians and the Soviet cultural order, "of the alliance between [...] the Ministry of Education and Culture led by Anatoli V. Lunatscharsky and the bourgeois intelligentsia" (Vasile, 2011) in the USSR. "More profoundly from the early 1960s, the cultural revolution becomes an integral part of the nationalistic discourse." (Vasile, 2011). From the pro-Soviet internationalism, the state had passed to Romanian nationalism, instrumentalising the national values and feelings. The limited "liberalisation", ever more visible after 1962-1963, must be understood in comparison with the Soviet-inspired censorship of the first communist decade.

\subsection{Other Documents Regarding the "Bulandra" Case}

Among "the measure proposals [...] approved in the meeting [...] of 6 July 1971 " in order to sharpen the class struggle, invoked by the disgruntled actors in their attack on Lucian Pintilie and his collaborators, the $12^{\text {th }}$ mentioned that "in the orientation of the repertoires of the performance, theatre, opera, ballet, music hall institutions accent will be placed on the promotion of original works of militant, revolutionary character; $[\ldots]$ a more rigorous selection of the works in the international classical and contemporary repertoire will be ensured.” (Malița, 2006). The militant, revolutionary character was to be found only too little in the staging The Government Inspector, as the mise-en-scène featured, according to the testimonies of some of the roughly 3000 people who participated in the open rehearsals or in one of the three representations, ironical hints to the practices of territorial inspection of the then authorities (Hlestakov was received with bread and salt, the Mayor limped like Leonid Brezhnev). There are several attempts at reconstructing the circumstances of banning the performance The Government Inspector, starting with the file drawn out by critic Ileana Popovici in 1990 for the first issue of the magazine Teatrul azi (Theatre today). This departed from 
"photographs [...], an issue from România literară (Literary Romania) [No. 40/1972], a poster and a performance programme" (The literary secretariate of the Bulandra Theatre, 1997), gathering supplementary information from interviews with personalities involved in the making of the performance (Virgil Ogăşanu, who played the character Hlestakov; Maxim Crişan, at that time the deputy director of the theatre) and from a written remembrance conveyed by the former deputy of the Council of Socialist Culture and Education, Ion Brad. Republished in the anniversary volume The Bulandra Theatre 1947-1997, the file was completed by a fragment from the "unmasking act" read out in the party meeting following which the representations were interrupted. The ban was motivated by the lack of usefulness for society of the performance, which had been created in a way of working based on "professionalism per se, with a fetish for artistic virtues in an aestheticising spirit." (The literary secretariat of the Bulandra Theatre, 1997) Philosophically, the performance was being reproached the adherence to a concept "of idealistic essence regarding the cultural heritage", determined "by the influences of aesthetic trends in fashion in the West, as well, in the activity of artists who pragmatically keep their distance from Marxism." (The Literary Secretariate of the Bulandra Theatre, 1997). In other terms, the performance was being reproached the recontextualization to the detriment of illustrating the historical circumstances of the dramaturgical creation.

Toma Caragiu was symbolising the character of the situation of this staging through his double function as an actor in the role of the Mayor and as Party Secretary of the Theatre. In the latter quality, he had fallen prey to the anonymous signatories of the reporting notes, being accused, among other things, of submissiveness to the theatre management. In fact, in the role of the Mayor, as well, he would have caused a negative reaction from Maria Maurer, the wife of prime minister Ion Gheorghe Maurer, seated in the first row during one of the representations. After the "viewing", in which the CSCE (Ion Brad, Constantin Măciucă-manager of the theatres, Margareta Bărbuță, Marghit Marinescu (Pintilie, 2003)), RCP municipal and Cultural committee Bucharest (Amza Săceanu as president (The Literary Secretariate of the Bulandra Theatre, 1997)) representatives took part, Ion Brad communicated to Dumitru Popescu, then in the double function of RCP CC secretary with issues of culture and art and CSCE president, that the performance does not have any serious "problems". Consequently, Dumitru Popescu mandated Ion Brad to communicate to the theatre their agreement for the premiere. Cast in the performance in the role Abdulin, actor Petre Gheorghiu stated that the changes to the structure of the performance (seven, according to his testimony, six according to the assistant director, none of which was accepted by Lucian Pintilie) were requested after the second representation. In the interview given to critic Ileana Popovici, the deputy director of the Bulandra Theatre in 1972, Maxim Crişan, claims that the interpretation of a scene picturing a group of women dancing in Ukrainian costumes as 
ironical of Leonid Brezhnev's visits was diversionist in nature. The respective scene was requested to be eliminated, the reason being that it would cause "great international upsets". Also, Maxim Crişan considered that the invocation of a possible "upset" at the Soviet embassy was a pretext "for an arbitrary decision". The true triggering reason for the ban seems to have been the rivalry between the new secretary of the RCP CC Dumitru Popescu and members of the high cultural bureaucracy (Miron Constantinescu-member of the scientific council of the party history institute; Leonte Răutu-ideologist, head, în 1961, of the Directorate of Propaganda and Culture, secretary of the RCP CC-1966-1968responsable for the issues of work in schools or Cornel Burtică- "secretary of the RCP CC, with issues of propaganda in the respective period" (Tatos, 2010)), the stake being the degree of closeness to the Secretary General of the RCP. After the second representation, the performance was stopped. A director's hunger strike leads, in his interpretation, to the third and final representation, after which Lucian Pintilie is "summoned to the CC, where Dumitru Ghișe communicates to me the official banning decision. And adds.-And know this, comrade Pintilie, you will never work again in the ideological artistic field as long as you do not change your view on the world and universe..." (Pintilie, 2003)

Another line from that context, "assembled from several testimonies", would have been issued by the Secretary General of the RCP in a "meeting of the Central Committee": "Let him go and work in the West, let him see how hard it is and then he will return home". [...] The decision to ban the performance was read out on Television at the 20 o'clock news." (Pintilie, 2003). The Bulandra collective was summoned to an extended party meeting and advised to perform self-criticism. "From Dan Jitianu's testimony, inserted in Ion Cazaban's book, 'Dan Jitianu and the joy of communication' (The Cultural Foundation 'Camil Petrescu' \& the magazine 'Teatrul azi' (Theatre today), Bucharest, 2008), we find out that the board of the meeting was made up of Dumitru Ghişe, Ion Brad, Amza Săceanu, Constantin Măciucă." (Morariu, 2014). In the party meeting that followed, "a vote was held countless times on sacking the party secretary, but no one would raise their hand. [...] In the end Toma [Caragiu, o.n.] was the one who ended the absurd and embarrassing situation by asking his colleagues to vote as they are asked to (Dan Jitianu)" (Morariu, 2014).

Outside the political context, the raison d'être of censorship is given by the nature of the relationship between theatre and the public authorities, "stabilised in general in Europe" "from the $18^{\text {th }}$ century": "the theatres (the buildings and the practical context of performance production and presentation) are legally subordinated to the body that is responsible with public order (Department, Ministry, Police). [...] In the $19^{\text {th }}$ century, 'The Department for questions of the interior' had clear attributions in the field in the Romanian Principalities, as well. [...] from the Middle Ages until today, the attention towards the possible outbreak of a fire which could cause panic or accidents stayed at the origin of this special preoccupation." (Popescu, 2004) 


\section{Conclusion}

Within the political context of their manifestation, the effects of censorship in the works of theatre and cinema directed by Lucian Pintilie range from mild to severe. If his 1962 play The Fools under the Moonlight was weakened to the point of non-representation, his 1965 film Sunday at Six was criticised for straying from the path indicated in the script, that of a story of communist illegality, and veering towards a formalist love story in which the communist content slid into the background. His 1969 film Reenactment was only allowed three weeks of screening time, again encountering criticism related to the portrayal of state authorities, most notably the character of the warrant officer, one of the most memorably ridiculous figures in Romanian cinema. However, the strictest measure taken by the then authorities was to suspend Lucian Pintilie's right to work in Romania, a case presented by the only three representations of the play The Government Inspector, which was banned as a result of an "audience protest" staged for an article in the government daily Scânteia (The Star). The result was Lucian Pintilie's exile in France, where he continued to work as theatre director, engaging in a respectable career until the fall of the communist regime in 1989. The brief interlude of 1979, when Lucian Pintilie was invited to Romania to make a film after the works of celebrated national dramatist Ion Luca Caragiale, only confirmed his status of persona non grata, as the film material was confiscated before release and the opening night delayed until 1990.

The relation between the ratio theatre-public order and the warning expressed by Lucian Pintilie in a letter addressed to Liviu Ciulei, "that, if changes are brought to the content of the performance [The Government Inspector], he will set himself of fire in front of the Theatre" (Morariu, 2014) is marked by (self) ironical symbolism: "a very flattering portrait [...] this Palach-Pintilie diptych." (Pintilie, 2003). However, the relationship between theatre and censorship goes beyond irony or artistic skills. What remains is the way Lucian Pintilie showed open disregard for and even criticism against Stalin's rules in his film Reenactment and the manner in which he chose to mimic the authorities of the time in The Government Inspector-N. Ceauşescu by staging bread-and-salt receptions and Leonid Brezhnev by having one of the main characters limp like him.

Political and ideological control was exercised in communist Romania with the aim of restricting artistic creation to the precepts of socialist realism. In order to qualify as socialist realist, works of art had to observe four laws established by I. V. Stalin in 1934: they had to be realistic, proletarian, partisan and typical. Reenactment, directed by Lucian Pintilie în 1969, was criticising the latter two laws through the presence of the prosecutor, who was guiding the young men to create a future life observing society. The typical feature was being criticised through the character of the warrant officer, who was being ridiculous by trying to indicate to the young people how to act in the educational film. The filmic criticism of the authority representatives caused the reaction of the management forces. The performance The Fools under the Moonlight was modified several 
times on the recommendation of a viewing committee, with a consequence in weakening and having the performance forbidden despite the implemented changes.Reacting, in a first phase, to the imposition of the cultural revolution and against the laws of coagulating the socialist realist work of art, Lucian Pintilie managed from 1962 to 1972 to mark the Romanian theatrical and cinema landscape through the artistic quality of the directed performances and films, doubled by the renown of the applied bans. The halting of the performance The Fools under the Moonlight (1963), followed by the criticism applied to the film Sunday at Six (1965) for the formalist deviation from the theme of communist illegality concentrated the attention of the censorial structures on the Bulandra Theatre, considered influential through the staged performances, and on Lucian Pintilie, who, after Reenactment (1969) received a ban on directing films in Romania. In the field of theatre, a similar decision would be made by the authorities after three representations of the performance The Government Inspector (1972), which had fallen prey to the rivalry between cultural clerks close to Nicolae Ceauşescu, as well as to the critical orientation of Gogol's dramatic text (with a tradition of interdiction beginning with the age of the tsar and reaching the contemporary period under study, when a performance directed by the Russian artist Tovstonogov was being banned in Moscow).

In France, the Romanian director came up against the discouragement, similar to censorship, of a film project having paedophilia as a theme, which was rejected as a taboo. Analysing retrospectively the cases of the censored performances and films, three substantially different stages are singled out: if the first stage of creation until 1972 is marked by the difference between the criteria of artistic conception and the cultural policies of the period, Carnival Scenes coincided with a stage of communist nationalism sensitised to critical allusion; between urban systematisation and national representation, the carnival spirit could not find its place. Overcoming the political limitations imposed by the Romanian communist regime, Lucian Pintilie avoided, in the early 2000s, explicitly condemning the protagonists of his film project Jerusalem, a fact, which would have placed him ironically in the role of a censor of his own creation.

\section{Conflicts of Interest}

The author declares no conflicts of interest regarding the publication of this paper.

\section{References}

Boia, L. (2016). Strania istorie a comunismului românesc (The Strange History of Romanian Communism) (p. 137, 138). Bucharest: Humanitas.

Central Historical National Archives (1966). Fund of the CC of the RCP-The Section for Propaganda and Agitaion, File No. 31.

Central Historical National Archives (1970). Fund of the CC of the RCP-The Section for Propaganda and Agitation, File No. 18.

Central Historical National Archives (1971). Fund of the CC of the RCP-The Section for 
Propaganda and Agitaion, File No. 18.

Counsell, C. (1996). Signs of Performance (p. 46, 48). London and New York: Routledge.

Ficeac, B. (1999). Cenzura comunistă şi formarea "omului nou” (The Communist Censorship and the Shaping of the "New Man") (p. 34). Bucharest: Nemira.

Malița, L. (Ed.) (2006). Cenzura în teatru. Documente. 1948-1989 (Censorship in Theatre. Documents. 1948-1989) (p. 4, 6, 60). Cluj-Napoca: Efes.

Mazilu, T. (1971). Teatru (Theatre) (p. 115, 130). Bucharest: Cartea Românească.

Morariu, M. (8-10 January 2014). Scandalul Revizorului (The Scandal of the Government Inspector) (pp. 1-3). Daily Adevărul.

Pintilie, L. (2003).Bricabrac (p. 16, 25, 28, 306, 350, 351, 474). Bucharest: Humanitas. 2nd Edition (2017), Bucharest, Nemira.

Popescu, M. (2004). Scenele teatrului românesc, 1945-2004. De la cenzură la libertate. Studii de istorie, critică şi teorie teatrală (The Stages of Romanian Theatre, 1945-2004. From Censorship to Freedom. Studies of Theatre History, Criticism and theory) (p. 77, 80). Bucharest: Unitext.

Richards, D. (1986). Of Fierceness and Obsesstion. https://www.washingtonpost.com/archive/lifestyle/style/1986/03/02/of-fierceness-andobsession/7506f6d6-d783-472b-9326-72ecabc197ca/, 2016-8-1.

Selejan, A. (1999). Literatura în totalitarism, 1957-1958 (Literature in Totalitarianism, 1957-1958) (p. 425). Bucharest: Cartea Românească.

Şendrea, A. (July 2014). Realismul socialist între propagandă şi avangardă (Socialist Realism between Propaganda and Avant-Garde). Film Menu, No. 23.

Tatos, A. (2010). Pagini de jurnal (Diary Pages) (p. 344, 345). Bucharest: Nemira.

The Literary Secretariate of the Bulandra Theatre (1997). Teatrul Bulandra 1947-1997 (The Bulandra Theatre 1947-1997) (p. 46). Bucharest.

Transilvania Film, Filmex (2013). DVD Reenactment, the Collection Pintilie cineast (Pintilie the Movie-Maker).

Vasile, C. (2011). Politicile culturale comuniste în timpul regimului Gheorghiu-Dej (The Communist Cultural Policies during the Regime of Gheorghiu-Dej) (p. 31, 32, 219). Bucharest: Humanitas. 